\title{
STRATEGI PENGEMBANGAN INDUSTRI BUAH-BUAHAN DI JAWA TIMUR
}

Oleh :

\author{
M. Fatoni K *)
}

\begin{abstract}
ABSTRAK
Perkembangan sektor industri sangat erat kaitannya dengan proses industrialisasi sebagai grand design pembangunan ekonomi di Indonesia. Dalam menanggapi persaingan yang semakin tajam, maka setiap perusahaan harus selalu berusaha untuk meningkatkan efisiensinya. Semakin tinggi efisiensinya akan dapat memperbesar kemampuan perusahaan untuk menghasilkan keuntungan operasi perusahaan, baik dikaitkan dengan penjualan maupun modal yang digunakan untuk menghasilkan keuntungan tersebutBegitu banyak industri yang ada di Indonesia, apalagi di Provinsi Jawa Timur, yaitu baik industri yang bergerak di bidang jasa, konsumsi, transportasi, perhubungan dan yang lainnya. Untuk industri konsumsi dimana dalam hal ini industri makanan dan minuman, persaingan yang terjadi di antara perusahaan-perusahaan sangat ketat - mereka bersaing untuk memperoleh kepercayaan konsumen juga demi meningkatkan laba perusahaannya Dengan demikian untuk meningkatkan hasil industri khususnya industri makanan dan minuman di Provinsi Jawa Timur sendiri, perlu adanya pembaharuan dan peningkatan dalam setiap faktor-faktor produksi contohnya bahan baku, teknologi dan tenaga kerja sangat berperan khusus untuk meningkatkan sektor produksi suatu industri sehingga besar terhadap besar kecilnya proses produksi industri makanan dan minuman, Perdagangan dunia diperkirakan akan meningkat dengan tingkat pertumbuhan rata-rata sekitar $8 \%$ per tahun.
\end{abstract}

Kata kunci : industri, pembangunan ekonomi, strategi pengembangan industri

\section{PENDAHULUAN}

Perkembangan sektor industri sangat erat kaitannya dengan proses industrialisasi sebagai grand design pembangunan ekonomi di Indonesia. Sementara itu, dengan heterogenitas antar daerah yang besar dalam hal kekayaan alam serta faktor produksi lainnya, maka aspek dimensi daerah menjadi sangatlah penting dan strategis. Dimensi daerah yang paling utama yakni berkenaan dengan lokasi tiap jenis industri, dikaitkan dengan masalah efisiensi lokasi dan peningkatan produksi sektor industri, maka perhatian terhadap dimensi daerah akan terarah ke masalah keunggulan komparatif (comparative advantage) tiap daerah bagi suatu jenis industri tertentu.

Dalam menanggapi persaingan yang semakin tajam, maka setiap perusahaan harus selalu berusaha untuk meningkatkan efisiensinya. Semakin tinggi efisiensinya akan dapat memperbesar kemampuan perusahaan untuk menghasilkan keuntungan operasi perusahaan, baik dikaitkan dengan penjualan maupun modal yang digunakan untuk menghasilkan keuntungan tersebut.

Begitu banyak industri yang ada di Indonesia, apalagi di Provinsi Jawa Timur, yaitu baik industri yang bergerak di bidang jasa, konsumsi, transportasi, perhubungan dan yang lainnya. Untuk industri konsumsi dimana dalam hal ini industri makanan dan minuman, persaingan yang terjadi di antara perusahaan-perusahaan sangat ketat - mereka bersaing untuk memperoleh kepercayaan konsumen juga demi meningkatkan laba perusahaannya.

Seperti halnya laba yang akan diperbandingkan dapat berupa laba berasal dari operasi atau usaha, oleh sebab itu laba yang diperoleh dalam industri makanan dan 
minuman secara langsung dapat mempengaruhi pendapatan yang ditanggung oleh produsen industri makanan dan minuman khususnya di Provinsi Jawa Timur. Sehingga faktor-faktor mana yang dapat mempengaruhi dalam pembebanan pajak di sektor industri makanan dan minuman dimana dalam produksinya terdiri dari beberapa faktor yang dominan selain dari kinerja internal perusahaan tersebut, tetapi juga dari faktor eksternalnya dilihat dari persaingan dalam menarik konsumen sebanyak-banyaknya dan bertujuan memperoleh laba sebesar- besarnya.

Penerimaan Provinsi Jawa Timur tidak hanya diperoleh dari hasil kerajinan ataupun pariwisata yang mungkin mendapat perhatian yang cukup tinggi dan mampu menghasilkan devisa yang cukup besar bagi Provinsi Jawa Timur sendiri, melainkan juga dari produksi industri makanan dan minuman. Industri makanan dan minuman di Provinsi Jawa Timur memang cukup banyak dan saling bersaing untuk memenuhi permintaan konsumen, dan kerenanya sektor industri ini sangat potensial dalam mendukung perekonomian Provinsi Jawa Timur.

Jawa Timur merupakan barometer perekonomian nasional setelah DKI Jakarta, dan Provinsi Jawa Barat, sebab kontribusi PDRB Jawa Timur terhadap Produk Domestik Bruto (PDB) Nasional mencapai sekitar $16 \%$. Perekonomian Jawa Timur ditopang tiga sektor utama, yaitu perdagangan, industri, dan pertanian.

Total volume ekspor Jawa Timur pada 2006 mencapai nilai sebesar US\$ 8,35 milyar, naik $13,39 \%$ dibandingkan tahun 2005. Sedangkan net-ekspor pada 2006 sebesar US\$ 49,48 juta, meningkat 84,34\% dibandingkan tahun 2005. Untuk industri pengolahan di Jawa Timur pada tahun 2005 didominasi oleh industri kecil dan perdagangan kecil yang mencapai 97,76\% dari seluruh kelompok industri yang ada dan menyerap tenaga kerja dengan jumlah terbanyak, sisanya merupakan kelompok industri kimia, agro, dan hasil hutan (IKAHH) dan industri logam, mesin, elektronika dan aneka (ILMEA). Sektor industri di Jawa Timur mampu memberikan nilai produksi total sebesar Rp 12,10 triliun. Perusahaan industri besar dan sedang ada sebanyak 4.665 unit, dimana terbanyak pada kelompok industri makanan dan minuman.

Dengan demikian untuk meningkatkan hasil industri khususnya industri makanan dan minuman di Provinsi
Jawa Timur sendiri, perlu adanya pembaharuan dan peningkatan dalam setiap faktor-faktor produksi contohnya bahan baku, teknologi dan tenaga kerja sangat berperan khusus untuk meningkatkan sektor produksi suatu industri sehingga besar terhadap besar kecilnya proses produksi industri makanan dan minuman, Perdagangan dunia diperkirakan akan meningkat dengan tingkat pertumbuhan rata-rata sekitar $8 \%$ per tahun.

\section{RUMUSAN MASALAH}

Masalah-masalah mendasar yang perlu diselesaikan di sektor industri makanan dan minuman berbasis buah-buahan di wilayah Provinsi Jawa Timur antara lain meliputi:

a. Bahan Baku. Pasokan bahan baku tidak kontinyu karena produksi buah-buahan bersifat musiman, konsistensi mutu dan ukuran serta tingkat kematangan buah tidak merata disebabkan masih terbatasnya investasi budidaya perkebunan buah skala komersial; sebaran peta potensi buah secara komprehensif terbatas pada produk buahbuahan tertentu di Jawa Timur; terbatasnya penanganan teknologi pasca panen produksi buah-buahan dan penguasaan teknologi proses produksi di tingkat usaha skala kecil dan menengah masih rendah;

b. Produksi. Secara umum terdapat beberapa masalah pokok produk pertanian Jawa Timur, yakni: rendahnya daya saing produk pada aspek jaminan mutu/penerapan HACCP (Hazard Analytical Critical Control Point) dan jaminan suplai, manajemen distribusi, time delivery, cost efficiency, product appearance, tuntutan atribut produk misalnya kesesuaian dengan ISO series (ecolabeling, ecoefficiency), dan lain-lain sesuai dengan tuntutan pasar. Keseluruhan aspek tersebut merupakan hambatan ekspor yang menurut tata cara aturan perdagangan global WTO dimasukkan dalam kategori SPS (Sanitary dan Phytosanitary) dan TBT (Technical Barrier to Trade). Selanjutnya, dapat dikatakan bahwa permasalahan yang ada dalam industri makanan dan minuman berbasis buah-buahan di Jawa Timur adalah: (1) $\square$ Rendahnya kemampuan inovasi produk di bidang pengolahan buah; (2) Terbatasnya penerapan Good Manufacturing Practice (GMP), Hazard Analysis and Critical Control Point (HACCP) dan ISO 9000 series; dan (3) $\square$ Buah olahan umumnya diproduksi oleh industri skala kecil 
dan menengah yang masih terkendala dalam kemasannya.

c. Pemasaran. Kurangnya promosi pemasaran produk buah olahan di dalam negeri dan luar negeri. Pemasaran produk merupakan bagian terpenting dalam semua aktivitas dalam usaha mendistribusikan dan menjual produk hasil usaha. Produk-produk industri pengolahan industri makanan dan minuman berbasis buahbuahan di Provinsi Jawa Timur dalam hal ini masih kurang memperhatikan dari aktivitas pemasaran, promosi, kemasan, dan distribusi yang masih sangat sederhana belum mampu memenuhi efektivitas dalam pemasaran-nya, hal ini disebabkan karena sebagian besar dari kegiatan industri diusahakan oleh industri skala kecil dan menegah.

d. Infrastruktur. Masih rendahnya kemampuan penyediaan modal khususnya bagi pelaku industri skala kecil, yaikni dalam hal ini investasi dalam bidang industri makanan dan minuman berbasis buah-buahan yang sebagian besar diusahakan oleh industri usaha kecil dan menengah yang masih terkendala akan pemodalannya. Skala usahanya masih belum bisa memenuhi kebutuhan secara besar terhadap permintaan produk olahan buahbuahan baik secara regional maupun nasional, sehingga masih perlunya perolehan kemudahan dalam permodalan.

Mencermati analisis situasi dan beberapa permasalahan fundamental baik di lingkungan internal maupun eksternal yang telah dikemukakan, maka perlu diadakannya kajian dalam bentuk Pemetaan dan Rencana Aksi Pengembangan Industri Makanan dan Minuman Berbasis Buahbuahan di Provinsi Jawa Timur .

\section{TUJUAN}

Secara umum tujuan dari kegiatan Strategi Pengembangan Industri Makanan dan Minuman Berbasis Buah-buahan di Provinsi Jawa Timur adalah meningkatkan daya saing, yaitu ;

1. Terpenuhinya pemetaan industri yang sesuai dengan perkembangan industri makanan dan minuman berbasis buahbuahan di Provinsi Jawa Timur.

2. Bentuk rencana aksi pengembangan industri makanan dan minuman berbasis buah-buahan di Provinsi Jawa Timur berdasarkan hasil dari pemetaan yang telah dibuat.

\section{PROSPEK, POTENSI DAN ARAH PENGEMBANGAN}

\section{MANAJEMEN STRATEGI}

Dengan memperhatikan kaitan yang ada antara strategi dan tujuan perusahaan, maka pengertian manajemen strategik dapat dirumuskan dengan lebih transparan. Beberapa di antaranya manajemen strategik dapat didefinisikan sebagai berikut:

Pearce II dan Robinson, Jr. (1991):

.... Manajemen strategik merupakan kumpulan keputusan dan tindakan yang merupakan hasil dari rencana, fomulasi dan implementasi yang didesain untuk mencapai tujuan suatu perusahaan.

Suwarsono (1996):

.. Manajemen strategik dapat diartikan sebagai usaha manajerial menumbuhkembangkan kekuatan perusahaan untuk mengeksploitasi peluang bisnis yang muncul guna mencapai tujuan perusahaan yang telah ditetapkan sesuai dengan misi yang telah ditentukan

David (1998):

.... Manajemen strategik sebagai seni dan pengetahuan untuk merumuskan, mengimplementasikan, dan mengevaluasi keputusan lintas fungsional yang membuat organisasi mampu mencapai tujuannya.

Siagian (2001):

.... Manajemen strategik adalah serangkaian keputusan dan tindakan mendasar yang dibuat oleh manajemen puncak dan diimplementasikan oleh seluruh jajaran suatu organisasi dalam rangka pencapaian tujuan organisasi tersebut.

Umar (2001):

.... Manajemen strategik adalah seni dan ilmu untuk pembuatan (formulating), penerapan (implementing), dan evaluasi 
(evaluating) keputusan-keputusan strategik antar fungsi yang memungkinkan sebuah organisasi mencapai tujuan di masa datang.

\section{MODEL MANAJEMEN STRATEGI}

Meskipun para pakar memberikan definisi yang berbeda-beda tentang manajemen strategik - suatu hal yang biasa dalam kegiatan ilmiah - kiranya tidak akan jauh dari kebenaran apabila manajemen strategik didefinisikan sebagai serangkaian keputusan dan tindakan mendasar yang dibuat oleh manajemen puncak dan diimplementasikan oleh seluruh jajaran organisasi dalam rangka optimalisasi pencapaian tujuan dan berbagai sasaran organisasi yang bersangkutan. Dari definisi di atas, manajemen strategik memiliki tiga elemen penting, yaitu adanya tujuan yang ingin dicapai, perubahan lingkungan yang harus diantisipasi, dan strategi yang diimplementasikan.

Model manajemen strategik dibentuk untuk memberikan suatu kerangka berpikir yang mudah di dalam memahami bekerjanya manajemen strategik. Model tersebut dibentuk dari tiga elemen dasar manajemen strategik, yaitu analisis lingkungan, penetapan misi, visi dan objective serta strategi sebagai elemen akhir. Ketiga elemen dasar tersebut ditambah dengan komponenkomponen yang lain akan membentuk model manajemen strategik.

\section{Analisis Lingkungan.}

Analisis lingkungan dilakukan untuk mengetahui kemungkinan- kemungkinan peluang (opportunity) yang bisa muncul, serta kemungkinan-kemungkinan ancaman (threat) yang bisa terjadi yang diakibatkan oleh adanya perubahan-perubahan baik pada tingkatan lingkungan bisnis atau industri maupun lingkungan internal organisasi. Analisis lingkungan juga dilakukan terhadap kekuatan (strength) dan kelemahan (weakness) yang dimiliki organisasi untuk melihat seberapa besar organisasi dapat memanfaatkan peluang dan mengantisipasi ancaman yang muncul.

Lingkungan eksternal terdiri dari komponen-komponen atau variabel lingkungan yang berada atau berasal dari luar organisasi/perusahaan. Komponen tersebut lebih cenderung diperlakukan sebagai sesuatu yang given atau harus diterima, untuk selanjutnya bagaimana organisasi berkompromi atau menyiasati komponenkomponen tersebut.

Menurut Ali Sartono dalam NEED: Lingkungan, Manajemen, Ilmiah, Volume 2 No. 7 Juli 2000, bahwa dalam menilai lingkungan eksternal, manajemen harus memperhatikan sociental dan task environment. Sociental Environment, pengaruhnya bersifat umum dan tidak secara langsung menyentuh aktivitas jangka pendek dalam suatu organisasi, tetapi dapat mempengaruhi pengambilan keputusan perencanaan jangka panjang, seperti economics forces, technological forces, political-legal force dan sociocultural force.

Task Environment termasuk elemen atau kelompok yang secara langsung mempengaruhi perusahaan. Kelompok ini terdiri dari pemerintahan, kelompok lokal, supplier, pesaing, pelanggan, kreditor, serikat buruh, kelompok interest tertentu, dan asosiasi perdagangan.

Lingkungan internal terdiri dari komponen-komponen atau variabel lingkungan yang berasal atau berada di dalam organisasi/perusahaan. Komponen-komponen dari lingkungan internal cenderung lebih mudah dikendalikan atau di dalam jangkauan intervensi organisasi. Oleh karena berada di dalam organisasi, maka organisasi lebih memiliki bargain value untuk berkompromi atau menyiasati komponen-komponen yang berada di dalam lingkungan internal.

\section{DINAMIKA LINGKUNGAN STRATEGIS PROSPEK INDUSTRI MAKANAN DAN MINUMAN BERBASIS BUAH-BUAHAN}

Pada awal abad XXI diperkirakan akan terjadi perubahan radikal dalam struktur pasar dan kesempatan kerja yang berimplikasi pada pembentukan pasar baru, yaitu: (1) pada saat itu, kebutuhan dasar manusia telah tercukupi dan selera manusia bergeser pada kebutuhan sekunder dan tersier, sehingga kecenderungan ke depan, pasar jasa akan berkembang lebih cepat dibanding pasar barang; (2) pendapatan masyarakat makin tinggi dan lebih mengutamakan aktualisasi kepuasannya, sehingga segmentasi pasar 
makin mengarah pada kelompok individu yang makin kecil; dan (3) terjadi pergeseran permintaan antar individu dalam pasar barang dan jasa yang sama.

Sejalan dengan semakin ketatnya persaingan untuk memperoleh pangsa pasar, para pelaku usaha mengembangkan strategi pengelolaan rantai pasokan (Supply Chain Management, SCM) yang mengintegrasikan para pelaku dari semua segmen rantai pasokan secara vertikal ke dalam usaha bersama berlandaskan kesepakatan dan standarisasi proses dan produk yang bersifat spesifik untuk setiap rantai pasokan. Kunci daya saing produk antar rantai pasokan itu adalah efisiensi pada setiap segmen rantai pasokan dan keterkaitan fungsional antar segmen dalam memelihara konsistensi setiap pelaku dalam memenuhi kesepakatan dan standar yang digunakan. Untuk menciptakan hal tersebut diperlukan integrasi vertikal antar segmen rantai pasokan dan integrasi horizontal antar pelaku dalam satu segmen, misalnya integrasi diantara para produsen, diantara para distributor, dan diantara para pengumpul di dalam satu rantai pasokan yang sama. Kesepakatan internasional tentang perlindungan terhadap hak atas kekayaan intelektual (HaKI) melarang perusahaan domestik untuk meniru teknologi dan merek dagang yang telah dipasarkan oleh perusahaan asing.

Hal ini akan mendorong komersialisasi HaKI secara global. Perusahaan domestic yang menggunakan HaKI dan merek dagang asing harus membayar royalty berdasarkan kesepakatan bersama. Sebagai implikasinya, perusahaan multinasional akan merambah ke pasar domestik baik melalui investasi langsung maupun melalui kemitraan rantai-usaha (franchising), maupun dalam bentuk sewamenyewa merek dagang. Usaha franchising dan sewa merek dagang dalam bidang produksi barang-barang konsumsi domestik, seperti ayam goreng dan hamburger, akan meningkatkan perubahan pola konsumsi dan menimbulkan persaingan ketat dengan produk asli nasional. Mekanisme ini juga merupakan salah satu wahana baru bagi perusahaan multinasional untuk menguasai atau mengendalikan sektor agribisnis Indonesia. Disamping mengandung aspek negatif, franchising dan sewa merek dagang dapat bermanfaat dalam meningkatkan dayasaing dan perluasan pangsa pasar produk-produk pertanian, yang berarti berdampak positif bagi perkembangan agribisnis di dalam negeri.

Secara struktural, perekonomian Jawa Timur dikuasai oleh empat sektor utama yaitu sektor pertanian, sektor industri, sektor perdagangan, dan sektor pertambangan dan penggalian. Meski cukup dominan, sektor pertanian memiliki pertumbuhan relatif kecil sehingga pangsanya cenderung menurun. Kenyataan ini tidak mengejutkan mengingat elastisitas permintaan barang primer (termasuk pertanian) yang relatif kecil, serta perkembangan teknologi yang mengakibatkan cakupan sektor pertanian beralih menjadi sektor agroindustri, seperti pada kasus penggilingan padi.

Sektor perdagangan memiliki kontribusi yang relatif tidak stabil. Berbagai penelitian dengan menggunakan pendekatan model multiplier menunjukkan, multiplier perdagangan Jawa Timur relatif kecil. Hasil ini tidak terlalu mengherankan mengingat struktur ekonomi regional yang memungkinkan tingginya mobilitas barang dan faktor produksi mengakibatkan leakage (kebocoran) cukup besar dalam makro ekonomi Jawa Timur.

Mengingat kenyataan tersebut, pengembangan sektoral lebih efektif diorientasikan pada sektor industri. Sebab, sektor industri merupakan penggerak utama perekonomian wilayah, mengingat potensinya yang cukup besar dalam mengatasi masalah ketenagakerjaan (pengangguran), persediaan permintaan domestik, serta linked (keterkaitan) yang tinggi sektor industri dengan sektor lainnya baik secara backward maupun forward.

Dengan pangsa rata-rata mencapai $25 \%$ dari PDRB, ekspektasi terhadap sektor industri tidak terlalu berlebihan. Tahun 2007, pertumbuhan sektor industri mencapai $3,68 \%$, dan pada 2008 mengalami peningkatan menjadi $4,23 \%$.

Industri pengolahan dikelompokkan berdasarkan jumlah tenaga kerjanya ke dalam empat kategori, yaitu, pertama, industri besar adalah perusahaan industri yang memiliki pekerja 100 orang atau lebih. Kedua, industri sedang, yang mempunyai pekerja 20-99 orang. Ketiga, industri kecil yang memiliki tenaga kerja 5-19 orang. Dan, keempat, industri rumah tangga yang mempunyai pekerja 1-4 orang. Jumlah industri besar dan sedang di Jawa Timur pada 2007 sebanyak 
4.715 unit, dengan nilai output sebesar Rp 184,776 triliun.

Pertumbuhan jumlah unit usaha industri besar dan sedang di Jawa Timur dari tahun ke tahun cenderung meningkat dengan perkembangan rata-rata $2,90 \%$ per tahun selama 2003-2006, dengan nilai investasi perkembangannya rata-rata $7,74 \%$ per tahun, dan untuk penyerapan tenaga kerja rata-rata $3,42 \%$ per tahun, sedangkan untuk nilai produksi rata-rata meningkat sebesar $4,65 \%$ per tahun.

Perkembangan jumlah unit usaha industri kecil dan kerajinan rumah tangga di Jawa Timur rata-rata per tahun sebesar $2,64 \%$, dengan nilai investasi rata-rata sebesar $7,64 \%$ per tahun, dan untuk penyerapan tenaga kerja rata-rata sebesar $3,13 \%$ per tahun sedangkan untuk nilai produksinya per tahun rata-rata sebesar $3,96 \%$.

Potensi industri manufaktur di Jawa Timur pada 2006 tercatat 694.720 unit usaha, dengan investasi sebesar Rp 14.350 miliar dan nilai produksi sebesar Rp 12.685 miliar dan dapat menyerap sebanyak 2.576.176 tenaga kerja. Sedangkan pada 2007, dengan jumlah 688.063 unit usaha, investasi $\mathrm{Rp}$ 95.594,79 miliar dan nilai produksi $\mathrm{Rp}$ $10.242,81$ miliar, mampu menyerap tenaga kerja 2.523.370 orang.

Volume ekonomi sektor industri pengolahan mulai pada 2007 mencapai Rp 151 triliun, dengan sumbangan terbesar dari subsektor industri makanan, minuman dan tembakau sebesar Rp 83,3 triliun. Sedangkan sektor perdagangan, hotel dan restoran apabila dirinci per subsektornya, terbesar disumbang oleh subsektor perdagangan, disusul subsektor hotel, dan restoran. Sektor industri pengolahan dan subsektor perdagangan selalu menjadi penyumbang terbesar dalam pembentukan volume ekonomi Jawa Timur.

Pertanyaan mendasar yang kemudian mengemuka, pertumbuhan sektor industri manufaktur yang terjadi ini akankah berkelanjutan (sustainable growth). Jawabnya, pasti ya, dengan syarat daya saing ditingkatkan melalui berbagai pembenahan mendasar. Sebab perkembangan nilai tambah industri belum sepenuhnya ditopang perbaikan efisiensi dan kemajuan produktivitas pekerja secara simultan. Selama ini pertumbuhan output industri lebih bersifat input driven dibandingkan productivity driven.
Peran produktivitas dan efisiensi dalam proses produksi sangat penting. Kegiatan ekonomi sektoral sering diasumsikan mengikuti fungsi produksi tertentu. Fungsi produksi adalah sebuah deskripsi matematis atau kuantitatif dari berbagai macam kemungkinan produksi teknis. Fungsi produksi memberikan output maksimum dalam pengertian fisik dari tiap-tiap tingkat input dalam pengertian fisik. Output suatu sektor industri akan dipengaruhi oleh input yang digunakan dalam proses produksi.

Secara umum input terbagi dalam dua jenis yaitu input fisik berupa tenaga kerja dan kapital, serta input lain berupa tingkat teknologi dan efisiensi produksi yang tercermin dari tingkat produktivitas. Kenaikan output sektor industri dengan demikian dapat disebabkan oleh dua hal, yaitu penggunaan input yang lebih banyak (input driven) atau dengan adanya peningkatan produktivitas. Dengan kata lain, kenaikan output bisa terjadi tanpa memerlukan adanya kenaikan dalam input secara kuantitas (productivity driven).

Dengan penggunaan input yang tetap tetapi penggunaannya lebih produktif/efisien, output juga bisa ditingkatkan. Kenaikan input yang lebih produktif bisa dilakukan dengan adanya manajemen produksi yang lebih baik, atau adanya teknik produksi yang lebih efisien.

\section{INDUSTRI INTI}

1. Industri puree adalah industri yang mengolah buah segar menjadi bubur buah melalui proses pelumatan, merupakan produk antara dari pengolahan buah dan menjadi bahan baku pada industri sari buah. Produk puree akan memudahkan dalam transportasi, mutu produk lebih konsisten dan daya simpan lebih lama sehingga kontinuitas bahan baku untuk industri lanjutan dapat terjamin.

2. Industri sari buah, juice merupakan proses lanjutan dari puree buah yang ditambah air dan bahan tambahan lain menjadi produk minuman yang siap dikonsumsi

\section{INDUSTRI PENDUKUNG/PENUNJANG}

1. Industri kemasan

2. Industri gula rafinasi

3. Industri flavours 
4. Industri pewarna dan pengawet

5. Industri mesin/peralatan

6. Jasa perbankan

7. Jasa transportasi

\section{INDUSTRI TERKAIT}

1. Meliputi industri yang menggunakan infrastruktur dan bahan baku yang sama.

2. Rencana industri pengolahan buah di Jawa Timur:
a) Sebagai sentra industri manisan buah mangga. Selain itu juga dikembangkan sirop mangga, juice mangga dan dodol mangga.
b) Penanganan dan pengemasan buah segar, khususnya buah mangga
c) Sebagai sentra juice mangga gedong
d) Sebagai lokasi industri kemasan

\section{STRATEGI PENGUSAHA DAN PERUSAHAAN}

Mengembangkan produk olahan pokok seperti mangga dan buah lainnya dengan sistem pencangkokan antara lain :

1. Industri juice dan sirup buah, akan dikembangkan/dicangkokkan pada industri minuman jeruk nipis.

2. Industri selai/jam dan dodol buah, akan dikembangkan/ dicangkokkan pada industri dodol.

3. Industri manisan kering dan buah basah, akan dikembangkan/ dicangkokkan pada industri manisan basah.

4. Industri konsentrat dan leather fruit, akan dicangkokkan pada industri sejenis.

5. Industri pengemasan buah mangga segar.

\section{PENINGKATAN DAYA SAING PRODUK AGRIBISNIS MELALUI PENDEKATAN KLASTER}

Peningkatan daya saing usaha kecil dan menengah yang berbasiskan agribisnis di Indonesia dapat dilakukan dengan mengembangkan konsep klaster, tujuan utama dari klaster adalah untuk meningkatkan daya saing produk dengan menekankan nilai efisiensi dalam penggunaan waktu dan jarak dalam menghasilkan suatu produk. Peningkatan nilai efisiensi ini akan mendorong turunnya biaya produksi dan biaya pemasaran suatu produk, pada akhirnya produk tersebut lebih kompetitif dipasaran dan memiliki daya saing yang lebih tinggi dibandingkan dengan produk sejenis yang dihasilkan oleh negara lain.

Berbicara tentang peningkatan daya saing dengan menerapkan sistem klaster, maka tidak lepas dari lokasi, penentuan lokasi suatu perusahaan individual merupakan keputusan yang didasarkan pada perpaduan dari berbagai faktor yang mempengaruhi, seperti biaya transportasi, harga faktor lokal, kemungkinan produksi dan subtitusi, struktur pasar, kompetisi dan informasi. Suatu perusahaan akan memutuskan apakah menguntungkan untuk berdiri sendiri atau memutuskan untuk berlokasi dekat dengan perusahaan sejenis. Upaya pengembangan agribisnis telah dilakukan oleh pemerintah namun masih terdapat berbagai kendala terutama dalam menjaga kualitas produk yang memenuhi standar pasar internasional serta kontinuitas produk sesuai dengan permintaan pasar maupun untuk mendukung suatu industri hilir dari produksi pertanian.

Pengembangan agro-based cluster dapat dilakukan dengan mengembangkan sentra-sentra yang telah ada di Indonesia. Pengembangan klaster di bidang agribisnis di Indonesia lebih ditekankan kepada subsistem agribisnis di hulu dan di hilir serta sektor penunjang. Diharapkan implikasi dari pengembangan ini mampu mendorong transformasi sistem agribisnis di Indonesia dari agricultural-based economy menjadi agroindustri-based economy.

Pengembangan sentra komoditas agribisnis menuju klaster agribisnis harus lebih menekankan pada pola-pola pengembangan antara lain seperti :

1. Market Driven, selalu berfokus pada upaya mempertemukan sisi penawaran dan permintaan.

2. Inclusive, mencakup tidak hanya perusahaan berskala keci dan menengah saja tetapi juga perusahaan besar dan lembaga pendukung.

3. Collaborative, selalu menekankan solusi kolaboratif pada isu-isu daerah dari seluruh stakeholder.

4. Strategic, membantu stakeholder menciptakan visi strategis daerah yang menyangkut ekonomi.

5. Value-creating, mengupayakan penciptaan atau peningkatan nilai tambah daerah.

Tingkat keberhasilan pengembangan klaster Agribisnis tersebut harus terukur dan dapat dilihat parameter keberhasilannya. 
Tujuannya agar mudah dilakukan evaluasi dan perbaikan di masa datang terhadap program-program yang dikembangkan untuk membangun suatu klaster agribisnis di Indoensia.

Pengukuran tingkat keberhasilan sistem klaster dapat diukur dengan :

1. Terciptanya kemitraan dan jaringan yang baik, ditandai dengan adanya kerjasama antar perusahaan, hal ini menjadi sangat penting karena menyangkut ketersediaan sumberdaya, pembiayaan dan fleksibelitas serta proses pembelajaran bersama antar perusahaan.

2. Adanya inovasi, riset dan pengembangan. Inovasi secara umum berkenaan dengan pengembangan produk atau proses, sedangkan riset dan pengembangan berkenaan dengan pengembangan teknologi dan ilmu pengetahuan

3. Tersedianya sumberdaya manusia (tenaga kerja) yang handal. Dengan SDM yang handal, keberadaan kapital maupun kelembagaan dapat dijalankan dengan baik.

4. Terspesialisasinya aktifitas usaha perusahaan di dalam cluster (homogen) yang saling membantu antar sub sistem namun tidak menimbulkan ketergantungan antar perusahaan karena terciptanya persaingan yang sehat antara perusahaan sejenis.

5. Lokasi yang sesuai, Lokasi klaster yang dimaksud adalah memiliki tujuan untuk mengukur keberlanjutan dari aktivitas industri yang ada di lokasi tersebut. Faktor yang terkait dengan lokasi klaster ini adalah ketersediaan sumberdaya (input = bibit, pupuk, tenaga kerja) dan lahan, biaya transportasi, harga faktor lokal, kemungkinan produksi dan subtitusi, struktur pasar, kompetisi dan informasi. Tujuan akhirnya adalah tercapainya suatu efisiensi dan efektifitas serta keberlanjutan dalam pengelolaan untuk menghasilkan komoditi unggulan dari klaster tersebut.

Dukungan lain dalam menentukan berhasil atau tidak nya suatu klaster adalah pentingnya dukungan pemerintah baik berupa kebijakan (policy) maupun pembinaan terhadap sistem klaster yang sedang berkembang.

\section{LOKASI PENELITIAN}

Penelitian dilakukan dengan mengambil lokasi di Provinsi Jawa Timur, yaitu pada beberapa perusahaan industri makanan dan minuman berbasis buah-buahan, komunitas atau masyarakat industri dan pemangku kepentingan (stakeholders) yang berperan dalam pengembangan industri yang dipandang representatif untuk mendapatkan informasi atau data dari populasi dimaksud, yaitu diambil dari beberapa kabupaten di wilayah Provinsi Jawa Timur sebagai kabupaten yang memiliki industri makanan dan minuman berbasis buah-buahan yang berperan dalam pembangunan industri regional maupun nasional.

\section{DESAIN DAN METODE PENELITIAN JENIS DAN RANCANGAN PENELITIAN}

Berdasarkan jenisnya, penelitian dapat diklasifikasikan ke dalam: (1) penelitian survai; (2) penelitian eksperimen; (3) grounded research; (4) kombinasi pendekatan kuantitatif dan kualitatif; dan (5) analisis data sekunder (Singarimbun dan Effendi, 1995:1). Berdasarkan klasifikasi tersebut, penelitian ini termasuk dalam jenis penelitian survai (survey research). Penelitian survai di dalam penelitian ini digunakan untuk maksud penjelasan (explanatory), yakni diarahkan untuk menjelaskan pemetaan, road map dan rencana aksi pengembangan industri industri makanan dan minuman berbasis buah-buahan.

Selanjutnya, oleh karena informasi atau data tentang pemetaan dan rencana aksi pengembangan industri makanan dan minuman berbasis buah-buahan diperoleh berdasarkan pandangan, tanggapan, persepsi atau penilaian dari manajemen industri, komunitas atau masyarakat industri dan pemangku kepentingan (stakeholders) yang berperan dalam pengembangan industri dimaksud sebagai sumber data primer, maka penelitian ini juga termasuk dalam penelitian persepsional (perception research) (Indriantoro dan Supomo, 2002:256). 


\section{INSTRUMEN PENELITIAN}

Instrumen utama yang digunakan dalam penelitian ini adalah kuisioner yang ditujukan kepada responden penelitian, yaitu beberapa manajemen industri, komunitas atau masyarakat industri dan pemangku kepentingan (stakeholders) yang berperan dalam pengembangan industri yang dipandang representatif untuk mendapatkan informasi atau data dari populasi dimaksud, yaitu diambil dari makanan dan minuman berbasis buah-buahan kabupaten, antara lain makanan dan minuman berbasis buah-buahan sebagai kabupaten yang memiliki industri makanan dan minuman berbasis buah-buahan yang berperan dalam pembangunan industri regional maupun nasional. Sebelum disebarkan kepada sampel manajemen industri, komunitas atau masyarakat industri dan pemangku kepentingan (stakeholders) terpilih sebagai sumber data primer atau responden sebenarnya, kuisioner tersebut diuji terlebih dahulu validitas dan reliabilitasnya, karena kusioner dikembangkan dari konsep teoritis variabel (Ghozali, 2001:52)

Uji validitas dalam penelitian ini menggunakan construct validity, yaitu diuji dengan mengkorelasikan masing-masing pertanyaaan atau item dengan skor total untuk masing-masing variabel. Suatu item pada kuisioner disebut valid jika koefisien korelasinya positif dan lebih besar dari 0,30 .
Uji reliabilitas dalam penelitian ini dilakukan dengan Cronbach Alpha. Instrumen penelitian dikatakan reliabel apabila memiliki nilai Cronbach Alpha lebih besar dari 0,60 (Nunnaly, 1978:39).

Sebelum instrumen penelitian (kuisioner) disebarkan kepada sampel manajemen industri, komunitas atau masyarakat industri dan pemangku kepentingan (stakeholders) terpilih sebagai sumber data primer atau responden sebenarnya, terlebih dahulu dilakukan pengujian terhadap 9 orang anggota manajemen industri, komunitas atau masyarakat industri dan pemangku kepentingan (stakeholders) yang direncanakan menjadi responden sebenarnya. Setelah itu dilakukan pengujian terhadap validitas dan reliabilitas instrumen penelitian (kuisioner). Setelah dilakukan perbaikan terhadap kuisioner, selanjutnya kuisioner disebarkan kepada seluruh sampel manajemen industri, komunitas atau masyarakat industri dan pemangku kepentingan (stakeholders)

atas, selanjutnya mentransfer peluang dan ancaman dari EFAS serta menambahkan kekuatan dan kelemahan dari IFAS ke dalam sel yang sesuai pada matrik SWOT (Gambar 3.1). Berdasarkan pendekatan tersebut, maka dapat dirumuskan alternatif strategi, yaitu Strategi SO, ST, WO, dan WT.

\begin{tabular}{|c|c|c|}
\hline 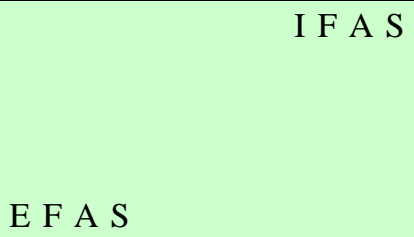 & $\begin{array}{c}\text { STRENGTH (S) } \\
\text { Menentukan 5-10 faktor } \\
\text { kekuatan internal }\end{array}$ & $\begin{array}{c}\text { WEAKNESS }(\mathrm{W}) \\
\text { Menentukan 5-10 faktor } \\
\text { kelemahan internal }\end{array}$ \\
\hline $\begin{array}{l}\text { OPPORTUNITY }(\mathrm{O}) \\
\text { Menentukan 5-10 faktor } \\
\text { peluang eksternal }\end{array}$ & $\begin{array}{c}\text { STRATEGI SO } \\
\text { Menciptakan strategi } \\
\text { yang menggunakan } \\
\text { kekuatan untuk } \\
\text { memanfaatkan peluang }\end{array}$ & $\begin{array}{c}\text { STRATEGI WO } \\
\text { Menciptakan strategi yang } \\
\text { meminimalkan kelemahan untuk } \\
\text { memanfaatkan peluang }\end{array}$ \\
\hline $\begin{array}{c}\text { THREAT }(\mathrm{T}) \\
\text { Menentukan 5-10 faktor } \\
\text { ancaman eksternal }\end{array}$ & $\begin{array}{c}\text { STRATEGI ST } \\
\text { Menciptakan strategi } \\
\text { yang menggunakan } \\
\text { kekuatan untuk } \\
\text { mengatasi ancaman }\end{array}$ & $\begin{array}{c}\text { STRATEGI WT } \\
\text { Menciptakan strategi yang } \\
\text { meminimalkan kelemahan dan } \\
\text { mengatasi ancaman }\end{array}$ \\
\hline
\end{tabular}

Gambar 4.1 Diagram Analisis Matrik SWOT 


\section{HASIL KEGIATAN}

Hasil kajian data eksisting, baik dari hasil survai instansional maupun survai di lokasi penelitian, dianalisis menurut kriteriakriteria berdasarkan tingkat kebutuhan dalam pembuatan rencana induk atau master plan pengembangan kawasan industri makanan dan minuman berbasis buah-buahan. Sementara itu, metoda analisis yang dilakukan dengan Sistem Informasi Geografis (SIG) adalah untuk menetapkan secara kewilayahan hasil analisis data struktural (dengan menggunakan analisis cluster atau kelompok), sehingga secara terintegrasi dapat disajikan deskripsi menyeluruh tentang rencana pengembangan kawasan yang diunggulkan.

Penentuan kawasan sentra produksi dikembangkan dari pengertian fungsi pertanian dalam arti luas. Semua wilayah daerah memiliki potensi yang sama untuk diseleksi berdasarkan potensi pertanian tanaman buah-buahan, berikut sarana dan prasarana penunjang yang terdapat di setiap wilayah daerah.

Dalam hal ini Provinsi Jawa Timur merupakan kawasan yang berpotensi untuk pengembangan buah-buahan yang mampu memberikan kontribusi nasional sebesar $20 \%$. Jenis buah buahan yang mempunyai nilai ekonomi tinggi dan jenis produksi buah buahan adalah mangga (Kabupaten Situbondo, Probolinggo, Pacitan dan Gresik), pisang (Kabupaten Lumajang, Magetan, dan Banyuwangi) dan jeruk (Kabuparen Pasuruan, Ponorogo, Madiun, Mojokerto, Pacitan, Magetan, dan Jombang). Dari kegiatan pemetaan dan pengembangan industri makanan dan minuman berbasis buah-buahan di wilayah Provinsi Jawa Timur diperoleh dapat digambarkan sebagai berikut:

1. Potensi buah tropis di wilayah Provinsi Jawa Timur sangat besar dan sebagian teknologi pengolahan buah telah dikuasai. Tersedianya tenaga kerja terampil dan adanya iklim tropis dan tanah yang bisa ditanami sepanjang tahun;
2. Ketidakpastian pasokan bahan baku karena buah bersifat musiman mengakibatkan petani kurang konsisten dalam memasok ke pabrik. Adapun budidaya perkebunan buah skala komersial belum masimal dilakukan karena masih rendahnya minat investasi. Lemahnya kemampuan ekspor langsung (direct-exporting) dan rendahnya inovasiproduk serta akses terhadap sumber informasi teknologi pasca panen buah;

3. Persaingan dengan negara produsen lainnya, seperti Thailand, Taiwan dan China. Ketatnya persyaratan mutu dari negara pengimpor terutama menyangkut penerapan GMP, HACCP, ISO, Sanitary dan Phytosanitary dan banyaknya buah segar ex-impor yang menguasai pasar lokal dengan harga murah.

\section{KESIMPULAN}

Dokumen Rencana Aksi Pengembangan Industri Makanan dan Minuman Berbasis Buah-buahan Provinsi Jawa Timur ini pada dasarnya menjabarkan suatu perencanaan strategis yang erat kaitannya dengan keberlangsungan dan peran industri khususnya industri makanan dan minuman berbasis buah-buahan di Provinsi Jawa Timur dalam perkembangannya, apa yang hendak dicapai, bagaimana mencapainya, dan langkah-langkah strategis apa yang perlu dilakukan agar tujuan yang telah ditetapkan dapat tercapai dengan efektif, efisien, dan tepat waktu sesuai dengan visi dan misi yang telah dicanangkan.

Kerjasama yang senantiasa ditingkatkan antara Pusat Kajian Makanan Tradisional dengan Badan atau Unit Kerja di daerah diharapkan pengembangan industri makanan dan minuman berbasis buah-buahan di Provinsi Jawa Timur mengalami kemajuan yang semakin signifikan terutama dalam mendorong peningkatan pertumbuhan ekonomi rakyat. Selain itu, diharapkan pula terjadinya penguatan koordinasi dan sinkronisasi kelembagaan antar sektor sehingga kualitas olahan makanan dan minuman buah-buahan semakin meningkat. 


\section{DAFTAR PUSTAKA}

Aronoff, S. 1989. Geographic Information Systems: A Management Perspective. Ottawa, Canada: WDC Publications.

Burrough PA. 1986. Principles of Geographical Information System for Land Resourcess Assessment. Clarendon. Oxford.

BPS [Biro Pusat Statistik].2011. Statistik Industri Besar dan Sedang. Jakarta: Biro Pusat Statistik.

2010.Jatim Dalam

Angka. Surabaya: Biro Pusat Statistik.

2006.Statistik Industri

Besar dan Sedang.Jakarta :Biro Pusat Statistik.

.Tanpa tahun.Peraturan Kepala Badan Pusat StatistikNomor 57 Tahun 2009 Tentang Klasifikasi Baku Lapangan Usaha Indonesia.Jakarta :Biro Pusat Statistik.

Departemen Perindustrian. 2009. Peta Panduan: Pengembangan Klaster Industri Prioritas Industri Penunjang Industri Kreatif dan Industri Kreatif Tertentu Tahun 2010 - 2014. Jakarta: Departemen Perindustrian.

Departemen Perindustrian Provinsi Jawa Timur. 2011. Pelaksanaan Kebijakan Pembangunan Industri Jawa Timur [paper]. Disampaikan dalam acara Forum Komunikasi Perencanaan Industri. Surabaya.

Department of Agriculture and Food Australia. 2009. Plan to Support Food Industry Development 2009 - 2012. Perth. Western Australian Agriculture Authority.Diakses darihttp://www.agric.wa.gov.au/objtwr/ imported_assets/content/fm/food_indus try_development_plan.pdf [21

November 2012]

Dumairy. 1996. Perekonomian Indonesia.

Jakarta: Erlangga.
GAPMMI [Gabungan Pengusaha Makanan dan Minuman Indonesia]. 2011. Outlook Industry Makanan Minuman 2011: Tantangan Kenaikan Harga Bahan Baku Pangan \& Peningkatan Daya Saing. Diakses dari http://www.gapmmi.or.id/?pilih=lihat\&id $=96[15$ Maret 2013]

Hearn P Jr. et al. 2012.Global Geographic Information Systems.USGS. http://webgis.wr.usgs.gov/globalgis/index .html. [ 1 Maret 2013].

Klosterman RE. 1999. The What if? Collaborative Planning Support System. Environmet and planning (26): 393 - 408.

Media Industri. 2011. Tingkatkan Daya Saing di Pasar Global. Media Industri No.03 Diakses dari www.kemenperin.go.id/download/1283 [12 Desember 2012].

Marimin (2004).Pengambilan Keputusan Kriteria Majemuk. Jakarta: Grasindo.

Porter, M.E. 1990. The Competitive Advantage of Nations. Free Press, New York.

Prahasta dan Eddy. 2002. Konsep-konsep Dasar Sistem Informasi Geografis. Bandung: Informatika.

Saragih B. 2000. Agribisnis Berbasis Peternakan: Kumpulan Pemikiran. Bogor: USESE Foundation dan Pusat Studi Pembangunan Institut Pertanian Bogor.

Sukmadjaja A. 2010. Pengembangan Agribisnis Hortikultura di Jawa Timur. Balai Besar Pelatihan Pertanian. Di akses dari

www.bbppketindan.bppsdmp.deptan.go .id [5 April 2012]

Tambunan TH. 2001. Industrialisasi Di Negara sedang Berkembang :kasus Indonesia. Ghalia Indonesia, Jakarta. 
M.Fatoni K, Strategi Pengembangan Industri Buah-Buahan Di Jawa Timur

Turban. 2009. Decision Support System and Intelligent Sysrem. Yogyakarta: Penerbit Andi.
Undang - Undang Nomor 13 Tahun 2010

Tentang Hortikultura.Lembaran Negara Republik Indonesia Nomor 5170. 